\title{
NEURONAL COUNTING AND PARASYMPATHETIC DYSFUNCTION IN THE HEARTS OF CHRONICALLY Trypanosoma cruzi - INFECTED RATS
}

\author{
E. CHAPADEIRO; R.F.C. FLORENCIO; P.C. AFONSO; P.S.S. BERALDO; P.C. de JESUS \& L.F. JUNQUEIRA Jr.
}

\begin{abstract}
SUMMARY
Ten male Wistar rats, chronically infected with Colombian, São Felipe (12SF) and Y strains of Trypanosoma cruzi and ten non-infected control animals were submitted to the bradycardia responsiveness test, an assessment of heart parasympathetic function, after phenylephrine injection. Six chagasic animals showed heart parasympathetic dysfuntion characterized by reduction in the index of bradycardia baroreflex responsiveness, as compared with the control group.
\end{abstract}

Microscopic examination of the atrial heart ganglia of chagasic rats showed ganglionitis, but no statiscally significant reduction in the number of neurons.

KEY WORDS: Cardiac parasympathetic dysfunction; Experimental Chagas' disease; Ncuroganglionitis; T. cruzi; Ncuronal counting.

\section{INTRODUCTION}

Previous works have demonstrated that in chronic chagasic paticnts ${ }^{2,3,13,14,15}$ and rats chronically infected with $\mathbf{T}$. cruzi ${ }^{6,16}$, depression of the baroreflex autonomic control of cardiac rhythm is mainly due to disturbed efferent parasympathetic function as a conscquence of neuroganglionitis in the heart.

However, no correlation was clearly yet established between the degree and nature of the lesions in cardiac intrinsic innervation and the reflex parasympathetic dysfunction. This correlation would have made possible an evaluation of the qualitative and quantitative involvement of intracardiac neurons in the production of the autonomic functional disturbance.

Thus, the present work aims to correlate cardiac denervation to the parasympathetic function in the rat model of chagasic infection. Following the assessment of cardiac autonomic function based on baroreflex bradycardia responsiveness in rats chronically infected with three strains of Trypanosoma cruzi, counts were taken on the numbers of neurons in the ganglia of the hearts of these rats.

\section{MATERIAL AND METHODS}

Ten male Wistar rats weighing between 50 and 80 grams were intraperitoneally inoculated with 4000 to 5000 blood forms per gram body weight of São Felipc (12SF), Y and Colombia strains of T. cruxi, at 25 to 30 days of age. Ten non-infected age-matched male rats were used as controls.

After the eighth month of observation, both infected and control animals were submitted in a conscious state to several intravenous bolus injections of 3 to $12 \mu \mathrm{g}$ of the pressor drug,

Work developed at the Cardiovascular Laboratory, Department of Clinical Medicine, Ilealth Sciences School, University of Brasilia (Brasilia, DF) and at the Post-Graduate Course in Iluman Pathology, Triângulo Minciro Medical School (Uberaba, MG).

Supponed by the Consclho Nacional de Desenvolvimento Científico e Tecnológico (CNPq) (Processos 40.3748/82, 13.4168/85, $30.1705 / 85,80.1004 / 86)$.

Address for correspondence: Prof. E. Chapadeiro, Faculdade de Medicina do Triângulo Mineiro, Praça Thomaz Uthôa, 706. CEP 38025 Ubcraba, MG, Brasil. 
CHAPADERO, E; FLORENCIO, R.F.C.; AFONSO, P.C.; BIRALDO, P.S.S.; JESUS, P.C. de \& JUNQUEIRA Jr., L.F. Neuronal counting and parasympathetic dysfunction in the hearts of chronically Trypanosoma cruzi - infected rats. Rev. Inst. Med. trop. S. Paulo, 33 (5): 337-341, 1991.

phenylephrine, for cvaluation of cardiac parasympathetic function. The autonomic function was $\mathrm{ex}-$ pressed by the baroreflex bradycardia responsiveness estimated as the ratio between the maximum percent decrement of heart rate obtained from the blood pressure recording, and the maximum percent increment of systolic arterial pressure $(-\Delta \%$ $\mathrm{HR} / \Delta \% \mathrm{SAP}$ ) following phenilephrine injections, in relation to the control values. For each rat, a mean index of bradycardia was calculated from the multiple injections (6 to 10) of phenilephrinc.

Methodological details on the present model of chagasic infection and on the cardiac autonomic function evaluation were described in previous works $s^{6,16}$.

After the autonomic function study, the rats were sacrificed, the hearts removed and sectioned sagitally in two halves and fixed with $10 \%$ neutral formaldehyde, and embedded, in paraffin. The entire paraffin block was serially sectioned and every seventh $5 \mu \mathrm{m}$ section was mounted and stained with hematoxylin and cosin (HE). Additional intercalated sections were also mounted for other stains (trichrome, cresyl-violet), including immunostaining for identification of T. cruzi (immunoperoxidase-antimmunoperoxidase). Neurons were counted on every $7^{\text {th }}$ section since the rat neuron size averages around $35 \mu \mathrm{m}$.

Statistical comparisons between chagasic and control groups of rats were performed employing the non-parametric Mann-Whitncy test, at a twotailed significance level of $5 \%(p<0.05)$.

\section{RESULTS}

After 8 months of infection most of the hearts examined histologically showed similar pathological alterations to that observed in human chronic Chagas'disease, especially in the indeterminate form ${ }^{6.9}$. The ganglia and nerve twigs in the atria of six hearts showed mild to intense $(+$ to +++$)$ in-

\section{TABLE}

Index of baroreflex bradycardia responsiveness, cardiac ganglionic inflammatory lesions and ncuronal counting in chagasic rats infected with Colombian (C), São Felipe (SF) and $Y$ strains of T. cruzi, and in control rats.

\begin{tabular}{|c|c|c|c|c|c|c|c|}
\hline \multirow[b]{2}{*}{ PROTOCOL } & \multicolumn{2}{|c|}{ CHAGASIC RATS } & \multicolumn{5}{|c|}{ CONTROL RATS } \\
\hline & $\begin{array}{c}\Delta \% \mathrm{HR} / \Delta \% \mathrm{SAP} \\
(\mathrm{bpm} / \mathrm{mmHg})\end{array}$ & $\begin{array}{l}\text { GANGLIONIC } \\
\text { LESIONSS }\end{array}$ & $\begin{array}{l}\text { NEURONAL } \\
\text { COUNT }\end{array}$ & PROTOCOL & $\begin{array}{l}\Delta \% \mathrm{HR} / \Delta \% \mathrm{SAP} \\
(\mathrm{bpm} / \mathrm{mmH} \mathrm{mg})\end{array}$ & $\begin{array}{l}\text { GANGLIONIC } \\
\text { LESIONS }\end{array}$ & $\begin{array}{c}\text { NEURONAL } \\
\text { COUNT }\end{array}$ \\
\hline C2 EA 4.20 & -0.79 & none & 2253 & N1 ET 3.20 & -0.84 & none & 2258 \\
\hline C5 EP 4.25 & $-0.04 *$ & t+ & 2321 & NI EV 3.60 & -0.51 & none & 2443 \\
\hline C6 DA 4.36 & -0.51 & + & 3827 & N2 DEA 3.20 & -0.51 & none & 3133 \\
\hline SF3 DEV 1.23 & $-0.45^{*}$ & none & 3354 & N2 DT 3.24 & -0.84 & none & 2418 \\
\hline SF4 DTEA 1.38 & $-0.26^{*}$ & t+ & 3194 & N2 DPEA 3.22 & -0.55 & none & 3444 \\
\hline SF5 DTEV 1.45 & $+0.03 *$ & +++ & 3670 & N2 EV 3.18 & -0.47 & none & 5350 \\
\hline Y4 DT 2.26 & -0.51 & + & 4896 & N3 DT 3.26 & -0.61 & none & 2902 \\
\hline Y4 EP 2.28 & -0.55 & none & 3057 & N3 ET 3.25 & -0.78 & none & 3529 \\
\hline Y5 DA 2.35 & $-0.33^{*}$ & none & 4257 & N3 DEV. 3.29 & -0.83 & none & 4909 \\
\hline Y5 DP 2.34 & $-0.30^{*}$ & $\mathrm{H+}$ & 3083 & N4 ET 3.31 & -0.61 & none & 2476 \\
\hline Median & $-0.39 *$ & & $3274+$ & & -0.61 & & 3017 \\
\hline Lower quartile & -0.51 & & 3057 & & -0.83 & & 2443 \\
\hline Upper quartile & -0.26 & & 3827 & & -0.51 & & 3529 \\
\hline
\end{tabular}

IIR = heart rate

$\mathrm{SAP}=$ systolic arterial pressure

$\triangle \% I I R / \triangle \% S A P=$ index of baroreflex bradycardia responsiveness

${ }^{*} \mathrm{p}<0.01$ compared with control group (Mann-Whitney test)

$+p>0.05$ companed with control group (Mann-Whitney test) 
CHAPADEIRO, E.; FLORENCIO, R.F.C.; AFONSO, P.C.; BERALDO, P.S.S.; JESUS, P.C. de \& JUNQUEIRA Jr., L.F. -

Neuronal counting and parasympathetic dysfunction in the hearts of chronically Trypanosoma cruzi - infected rats. Rev. Inst. Med. trop. S. Paulo, 33 (5): 337-341, 1991.

flammatory cell infiltration. There was a mononuclear infiltrate (macrophages, lymphocytes and plasma cells) surrounding neuronal degenerative changes (chromatolysis, vacuolation, hyperchromasia and retraction); necrosis and satellitosis were rarely observed (Figures 1 and 2). There were no morphological alterations in the remaining four

chagasic animals. Although amastigote forms of T. cruzi were noted in the myocardium of some rats, they were systematically absent in the ganglia of all animals.

On the other hand, there was no statiscally significant reduction $(p>0.05)$ in the number of atrial neurons in chagasic rats (me-

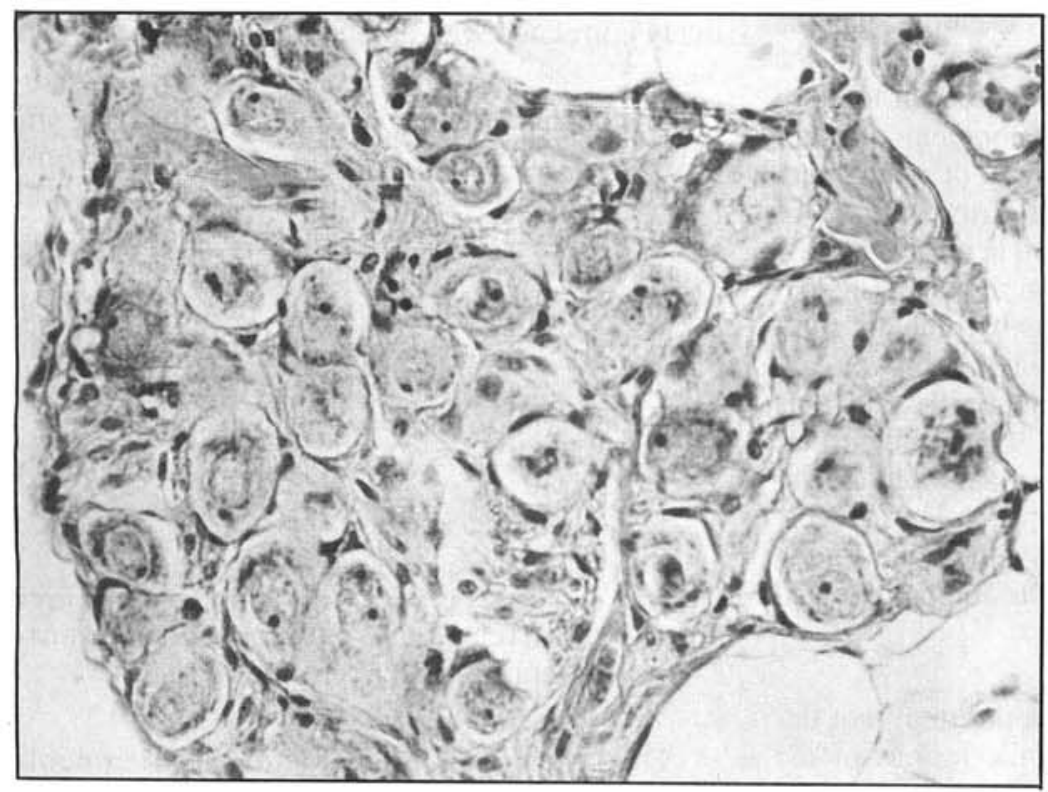

Fig. 1. Control rat. Normal aspect of atrial cardiac ganglia. HE 200x.

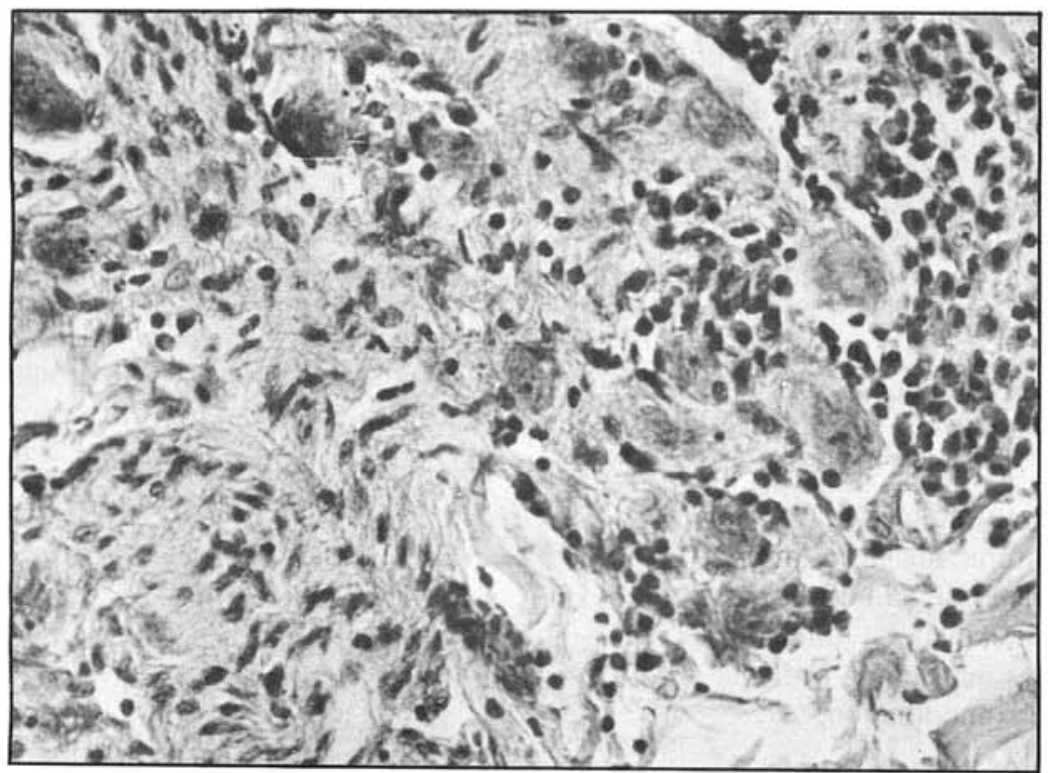

Fig. 2. Chronic chagasic rat. Mononuclear infiltration (plasma cells chiefly) of atrial cardiac ganglia; degenerative changes of ganglion cells. HE 200x. dian $=3274)$ as compared with control rats (median $=$ 3017).

With respect to the autonomic function, a significant $(p<0.01)$ reduction in the index of bradycardia baroreflex responsiveness was observed in the chagasic group of rats (median $=-0.39 \% \mathrm{bpm} /$ $\mathrm{mmHg}$ ) as compared with the control group (median $=$ $0.61 \% \mathrm{bpm} / \mathrm{mmHg}$ ). In $60 \%$ $(6 / 10)$ of the chagasic rats the bradycardia index was higher than the upper quartile of the control group (in relative values), i.i: parasympathetic dysfunction was observed. Of these chagasic rats, $66,6 \%$ (4) 6) exhibited neuroganglion inflammatory lesions in a variable degree. There were no lesions in parasympathetic cardiac plexus of two chagasic rats with depressed bradycardia responsiveness (SF3 DEV and Y5 DA). In two others rats with mild ganglionitis there was no change in the baroreflex response (C6 DA and Y4 DT).

The table lists the bradycardia responsiveness indices, the presence or absence of neuroganglion lesions and the neuronal counts for each chagasic and control rat.

\section{DISCUSSION}

Our findings confirm other reports ${ }^{6,16}$ that Wistar 
CHAPADEIRO, E.; FLORENCIO, R.F.C.; AFONSO, P.C.; BlERALDO, P.S.S.; JESUS, P.C. de \& JUNQUEIRA Jr., L.F. Ncuronal counting and parasympathetic dysfunction in the hearts of chronically 'Trypanosoma cruzj - infected rats. Rev. Inst. Med. trop. S. Paulo, 33 (5): 337-341, 1991.

rats chronically infected by São Felipe (12SF), Y and Colombian strains of 'T. cruzi, show parasympathetic cardiac dysfunction, characterized by reduced baroreflex bradycardic responsiveness after phenilephrine injection. These data also confirm experimentally those findings observed in chronic chagasic patients $2,3,13,14,15$. However, in chronic chagasic rats we did not find a significant reduction of neurons (denervation) in the cardiac ganglia as described in chagasics ${ }^{18,19,20,21}$ patients. In the rat, the cardiac denervation does not seem to be of fundamental importance in development of autonomic heart dysfunction, as well as of other functional and autonomic disturbances of Chagas'chronic cardiopathy ${ }^{1.18}$. Therefore, the assessment of cardiac denervation in chagasic patients and in other animal models by time consuming counts of neurons, not always comparable ${ }^{24}$, may not be necessary. The qualitative lesions (ganglionitis and neuritis) may be sufficient for identifying the cause of cardiac autonomic dysfunction, as emphasized previously ${ }^{6,16}$. Yet perhaps even, this is not necessary since one of the chagasic rats without any neural lesion has showed autonomic dysfunction.

The parasympathetic dysfunction may not depend exclusively on the ganglionic lesions of the heart because, as was shown in some rats in the present study, they may be absent. In rats, as well as in chronic chagasic patients, the cardiac autonomic dysfunction might be explained also by lesions in others segments of the parasympathetic nervous system, as suggested on the basis of the abnormal ventilatory response ${ }^{13}$ due to involvement of the bulbar vasomotor center and of the efferent sympathetic pathway. A significant reduction in the number of neurons in the dorsal vagal and hypoglossal nuclei of chronic chagasics with and without megaesophagus has been noted ${ }^{20}$. In rats (infected with the same strains of 'T. cruzi, lesions were observed also in the cerebral cortex, the brain stem and the medulla oblongat $a^{12}$ ).

Others hypotheses have been formulated to $\mathrm{cx}$ plain baroreflex depression in chronic chagasic infection, such as block to the adrenergic stimuli by EVI antibody and immunoglobulins reacting to the plasmatic membrane of the Schwann cells ${ }^{17}$ with altcration of the baroreceptor reflex modulation.

On the other hand, in hypertensive cardiopathy in which reduced baroreflex sensitivity was noted ${ }^{8}$, no Icsions and/or significant neuronal reduction was found ${ }^{2 !}$.

Finally, cardiac autonomic dysfunction exists in diabetes mellitus, which is also associated with lesions in ganglia and nerves (sympathetic and parasympathetic) in the heart and elsewhere ${ }^{5,10,22 .}$ However, these alterations have not been quantitatively correlated with autonomic dysfunction.

In conclusion, the mechanisms of the parasympathetic autonomic dysfunction in chronic chagasic cardiopathy and its role in the pathophysiologic manifestations of the heart discase do not secm sufficiently clarified ${ }^{14,23}$. The chronic ' $\mathrm{T}$. cruzi infection in the rat can be an useful model ${ }^{6,9,16}$ for understanding chagasic and othcrs cardiopathics producing lesions in cardiac intrinsic innervation and autonomic dysfunction.

\section{RESUMO}

\section{Contagem neuronal e disfunçăo cardíaca parassimpática em ratos cronicamente infectados pelo Trypanosoma cruzi}

De\% ratos machos Wistar cronicamente infectados pelas cepas Colombiana, São Felipe (12SF), c Y do Trypanosoma cruzi, foram submetidos, após 8 meses de infeç̧ão, juntamente com de\% animais controles, ao teste da resposta bradicárdica barorreflexa pela injeção endovenosa de fenilefrina. Scis ralos chagásicos exibiram disfunção cardiaca parassimpática, caracterizada pela depressão do índice da resposta bradicárdica barorreflexa.

Embora o estudo histológico dos corações chagásicos mostrasse lesões dos gânglios atriais, a contagem dos neurônios $\mathrm{cm}$ cortes scriados, não apresentou redução numérica significativa dos mesmos.

\section{RIIIERIENCES}

1. ALCÂNIARA, I.G. - Sistema neuro vegetativo do coração, na moléstia de Chagas Experimental. Rev. goiana Med., 7: 111-126, 1961.

2. AMORIM, D.S.; GODOY, R.A.; MANÇO, J.C.; TANAKA, A. \& GALLO Ir., L. - Efffects of acute elevation in blood pressure and atropine on heart rate in Chagas'diseasc. Circulation, 38: 289-294, 1968. 
CHAPADEIRO, E.; FLORGNCIO, R.F.C.; AFONSO, P.C.; BERALDO, P.S.S.; JESUS, P.C. de \& JUNQUEIRA Jr., L.F. Neuronal couning and parasympathetic dysfunction in the hearts of chronically Trypanosoma cruzi - infected rats. Rev. Inst. Med. trop. S. Paulo, 33 (5): 337-341, 1991.

3. AMORIM, D.S.; MELLO DE OLIVLIRA, J.A.; MANÇO, J.C.; GALLO Jr., L. \& MEIRA DE OLIVHI. RA, J.S. - Chagas'heart disease: first demonstrabic correlation between neuronal degencration and autonomic impaiment. Acta Cardiol., 28: 431 -440, 1973.

4. AMORIM, D.S. \& OLSIEN, E.G.J. - Assessment of heart neurons in dilated (congestive) cardiomyopathy. Brit. Heart J., 47: 11-18, 1982.

5. APPENZELLIR, O. \& RICIIARDSON, I..P. - The sympathetic chain in patients with diabctic and alcoholic polyneuropathy. Neurology, 16: 1205-1209, 1966.

6. BERALDO, P.S.S.- Sobre a infecção chagásica experimental no rato. Estudo cletrocardiográfico scriado e funcional autonômico do coração correlacionado à histopatologia. Brasília, 1987. (Dissentação de MestradoUniversidade de Brasília).

7. BOIM, G.M. - Quantitative study of the intrinsic innervation of the heart in endomyocardial fibrosis and African cardiopathics. Rev. Inst. Med. trop. S. Paulo, 10: 84-87, 1968 .

8. BRISTOW, J.D.; HONDUR, A.J.; PICKERING, G.W.; SLEIGIIT, P. \& SMYTH, II.S. - Diminished baroreflex sensitivity in high blood pressurc. Circulation, 39: 48-54, 1969.

9. CIIAPADEIRO, E.; BERALDO, P.S.S.; JISSUS, P.C.; OLIVEIRA Ir., W.P. \& JUNQUEIRA Ir., L.F. - l.esỏes cardíacas em ratos Wistar inoculados com diferentes cepas do Trypanosoma cruzi. Rev. Soc. bras. Med. trop., 21 : 95-103, 1988.

10. DUCHEN, L.W.; ANIORIN, A. \& WAIKINS, P.J. Pathology of autonomic neuropathy in diabets mellitus. Ann. intern. Med., 92: 301-303, 1980.

11. EKIBIRG, D.; DRABINSKY, M. \& BRAUNWAL.D, L. Defective parasympathetic control in patients with heart disease. New Engl. J. Med., 285: 877-885, 1971.

12. FENELON, S.B.; CIIAPADHIRO, E.; BIERALDO P.S.S. \& JUNQUEIRA Jr., L.F. - Lesóes histológicas do encéfalo de ratos albinos Wistar infectados com três cepas do Trypanosoma cruzi. (Abstracl). Rev. Soc. bras. Med. trop., 22: (Supl. II): 77, 1989.

13. IOSA, D.J.; CAIERO, D.F. \& PALMIERO, J.A. Abnormal hyperventilation tests in chronic Chagas'disease. J, autonomic nerv. Syst., 2: 87-92, 1980.

14. JUNQUEIRA Jr., L.F. - Ambulatory assessment of cardiac autonomic function in Chagas'heart discase patients based on indexes of $R \cdot R$ interval variation in the Valsalva maneuver. Braz. J. med. biol. Res., 23: 1091 . $1102,1990$.

15. JUNQUI:IRA Jr., L.F.; GALLO Jr.; MANÇO, J.C.; MARIN NETO, I.A. \& AMORIM, D.S. - Subtle cardiac autonomic impairnent in Chagas'discase detected by baroreflex sensitivity testing. Braz. J. med. biol. Res., 18: 171-178, 1985.

16. JUNQUEIRA Jr., L.F.; BERALDO, P.S.S.; CIAPADEIRO, H. \& JESUS, P.C. - Impaired baroreflex autonomic control of heart rate and neuroganglionitis in an experimcntal chronic rat model of Trypanosoma cruzi (chagasic) infection (submitted, 1990).

17. KIHOURY, E.; COSSIO, P.M.; RITACCO, V.; DIE\%, C.; LAGUINS, R.P.; SIEGAL, A.; SZARFMAN, A. \& ARANA, R.M. - Tinción inmunolluorescente de nervio periférico assoaciada al anticucrpo EVI. Medicina (B. Aires), 36: 539, 1976.

18. KÖBIERLLE, F. - Patologia y anatomia patológica de la enfermedad de Chagas. Bol. Olic. sanit. panamer., 51: 404-428, 1961.

19. LOPIS, L.R. - Contribuição ao estudo dos gânglios cardiacos (sistema nervoso autônomo) $\mathrm{cm}$ chagásicos crônicos. Hospital (Rio de J.), 70: 1421-1433, 1966.

20. LOPISS, IE.R.; TARURI, W.I.. \& CIIAPADEIRO, E. - Estudo morfológico c quantiativo dos núclcos dorsal do vago e do hipoglosso $\mathrm{cm}$ chagásicos crônicos com $\mathrm{c} \mathrm{scm}$ megaesôfago. Rev. Inst. Med. trop. S. Paulo, 11: 123129,1969 .

21. LOPliS, B.R. - listudo comparativo dos gânglios subepicárdicos nas cardiopatias chagásica crônica, reumálica e hipertensiva. Rev. Inst. Med. trop. S. Paulo, 12: $365-374,1970$.

22. LOW, P.A.; WALSH, J.C. \& HUANG, C.Y. - The sympathetic nervous system in diabetic neuropathy. $\Lambda$ clinical and pathological study. Brain, 98: 134-365, 1975.

23. MARIN NIETO, J.A. - Alteraciones neurovegetativas cardiovasculares en la enfermedad de Chagas. Rev. Fed. argent. Cardiol., 17: 177-187, 1988.

24. OLIVIEIR $\Lambda$, J.M.S. - Patogênese da cardiopatia chagásica: revisão subre a problemática da destruiçāo neuronal. Rev. Soc. Cardiol. Ribeirāo Preto, 4: 9-15, 1980.

Recebido para publicą̧ão cm 20/12/1990. Accito para publicação cm 19/04/1991. 